\title{
The Development of Electronic Book with QR Code Technology and Interactive Exhibition Entitled "Media Literacy" for Undergraduate Students
}

\author{
Niranuch Peekeaw ${ }^{1}$, Pornpapatsorn Princhankol ${ }^{1} \&$ Kuntida Thamwipat $^{1}$ \\ ${ }^{1}$ Faculty of Industrial Education and Technology, King Mongkut's University of Technology Thonburi , Bangkok , \\ Thailand \\ Correspondence: Niranuch Peekeaw, Faculty of Industrial Education and Technology, King Mongkut's University of \\ Technology Thonburi, Bangkok, Thailand. E-mail: Niranuch.pee@cra.ac.th
}

Received: February 10, 2020 Accepted: April 20, 2020 Online Published: April 29, 2020

doi:10.5539/res.v12n2p55

URL: https://doi.org/10.5539/res.v12n2p55

\begin{abstract}
This research was aimed 1) to survey the needs, 2) to develop electronic book with QR code technology and interactive exhibition entitled "Media Literacy" for undergraduate students, 3) to examine the quality, 4) to examine the learning achievement and 5) to examine the satisfaction. The tools in this study consisted of needs survey form, electronic book with QR code technology and interactive exhibition entitled "Media Literacy" for undergraduate students, quality evaluation forms for contents and media presentation, learning achievement test, and satisfaction questionnaire. The sampling group in this study consisted of 40 third-year undergraduate students who enrolled in the ETM 314 Professional Experiences in Educational Technology and Mass Communication, Department of Educational Communications and Technology, Faculty of Industrial Education and Technology, King Mongkut's University of Technology Thonburi in the first semester of the academic year 2019. They were chosen using purposive sampling method. There were 9 experts in contents, media presentation as well as measurement and evaluation. The statistical methods were percentage, mean score, standard deviation and t-test. The research findings showed that the sampling group expressed the highest level of needs $(\overline{\mathrm{x}}=4.68$, S.D. $=0.47)$. The quality evaluation results showed that the quality of the contents was at a very good level $(\overline{\mathrm{X}}=4.73$, S.D. $=0.42)$ and the quality of the media presentation was at a good level $(\overline{\mathrm{x}}=4.42$, S.D. $=0.40)$. The learning achievement test results showed that their average post-test score was higher than their average pre-test score with statistical significance at the .05 level (t-test $=7.23$ ). The sampling group expressed the highest level of satisfaction towards the media $(\overline{\mathrm{x}}=4.68$, S.D. $=0.49)$. Therefore, the developed media could be distributed for further use.
\end{abstract}

Keywords: development, media literacy, QR code technology, interactive exhibition, electronic book

\section{Background and Significance}

The current society is an information society. With advances in information technology and rapid changes, communication channels have to be developed including senders, messages, recipients, and media or channels. In this era, media convergence is prevalent and it is likely to affect the next generation of people called "Millennials" who consider information technology to be the fifth factor in their social life. Therefore, it is important to acknowledge that new media and channels will play an influential role in their life and they will guide their thinking (Urapen Yimprasert, 2014).

Media literacy in the age of information technology and digital times is a set of competencies which cover skills in the $21^{\text {st }}$ century which involve the ability to access information through digital media and technology. It involves selection, analysis, evaluation and application of information in a creative manner and how to develop media. To drive the society, it is important to combine 3 kinds of competencies: Media Literacy, Information Literacy and Digital Literacy. They are also related to other sets of life skills such as Self-Management Skills, Thinking Skills, and Interpersonal and Communication Skills. Access to information and technology is a basic right of citizens and humankind. It is necessary to protect this right so that citizens can gain sufficient information from different sources of information when they think, make a decision and engage in practices, especially in democratic societies where there are many kinds of people. This right will be useful when people monitor and check the information given by the government and fight against the government, media corporates and businesses in order to change the society towards a fair society through this principle. Educational management which strives to integrate and combine these sets 
of skills is very important (Arphawan Sopontammarak, 2017).

At present, both technology and electronic media are playing a significant role in everyday life, including communication, business and information search. In education, technology is considered to be important and it is widely used for convenience and easy access. It is also used in instruction. Nowadays, more technologies are used in classroom as recommended by the government's policy (Ministry of Education, 2013). In order to create an up-to-date media and to allow students to learn effectively, various kinds of information are stored and distributed to schools and students. Sound and video clips are utilized and provided on computers as well as electronic devices such as smart phones and tablets which are widely popular nowadays. Due to the advances in technology and communication system, the current society cannot live without these handheld devices which support fast and effective distribution of news and information. The current educational policy and the direction of educational development are moving towards learner-centered education so that learners engage in life-long learning. Electronic books are one kind of media which can show animations and sounds and they allow users to have interaction with them; therefore, students can learn effectively and remember more contents (Suthilak Soonghanghwa, 2009). Furthermore, electronic books can be used in an online environment and this is compatible with distance learning method so that learners can learn the contents on their handheld devices or download the contents for further use.

QR Code (or Quick Response Code) was developed by Denso Wave, Japan. It is a 2D barcode which can store various kinds of texts including numbers and letters. The main objective was to increase the speed and the reliability of the system to check the machine parts. Denso Wave has been doing research and development continuously and now QR codes have been used for commercial purposes to increase the convenience and the effectiveness in reading and scanning the information on smart phones. Now QR codes store details on product labels, printed matter, memos and they are used in other situations such as education, security, medial service, tourism, marketing and customer service (Nattawut Boonrojwong and Kotchakorn Praporntrakarn, 2017).

Exhibition is a kind of educational activity which shows knowledge management through display of objects and materials as well as contents and information. Viewers can see, learn, test and engage in activities during the exhibition. Exhibition is a medium for education, knowledge, understanding, stimulating curiosity and changing viewer's behaviors to achieve a goal. Interactive exhibition is a kind of exhibition which allows participants to interact with the stimulants in the exhibition, resulting in more benefits during the exhibition (Nittaya Chatmueangpok, 2009).

According to the literature review of these studies: media literacy and the development of online media awareness and literacy (Nitida Wiwatpanit, 2015), the format of communication and information technology for Thai teenagers (Nattanan Siricharoen, 2015) and research as well as development of learning process for promoting the media literacy for Thai youth based on contemplative education (Patamaporn Pan-in, 2014), it was found that there was no study into the development of electronic book with QR code technology and interactive exhibition. Therefore, the researchers decided to develop an electronic book with QR code technology and interactive exhibition entitled "Media Literacy" for undergraduate students to promote media literacy among students and people who were interested in using the electronic book with QR code technology and interactive exhibition entitled "Media Literacy" so that they would be aware of the significance of media literacy and dangers of the media in the current society.

\section{Objectives}

a. To survey the needs regarding the development of an electronic book with QR code technology and interactive exhibition entitled "Media Literacy" for undergraduate students

b. To develop the electronic book with QR code technology and interactive exhibition entitled "Media Literacy" for undergraduate students

c. To examine the quality of the electronic book with QR code technology and interactive exhibition entitled "Media Literacy" for undergraduate students

d. To examine the learning achievement of undergraduate students who used the electronic book with QR code technology and interactive exhibition entitled "Media Literacy"

e. To examine the satisfaction of the undergraduate students who used the electronic book with QR code technology and interactive exhibition entitled "Media Literacy" 


\section{Research Scope}

\subsection{Contents of Electronic Book}

The electronic book with QR code technology and interactive exhibition entitled "Media Literacy" for undergraduate students contained 8 units as follows: 1) Why do we need media literacy?; 2) Dangers of cyberbullying; 3) How to develop media literacy skills; 4) Theories related to media literacy; 5) How to use online media with awareness; 6) Netiquette and ethics of IT users; 7) Law and moral code of mass media; and 8) social issues and risky situations.

\subsection{Population and Sampling Group}

The population in this study was 90 third-year undergraduate students who enrolled in the ETM 314 Professional Experiences in Educational Technology and Mass Communication, Department of Educational Communications and Technology, Faculty of Industrial Education and Technology, King Mongkut's University of Technology Thonburi in the first semester of the academic year 2019 (Registrar's Office KMUTT, 2019). The sampling group consisted of 40 third-year undergraduate students who enrolled in the ETM 314 Professional Experiences in Educational Technology and Mass Communication, Department of Educational Communications and Technology, Faculty of Industrial Education and Technology, King Mongkut's University of Technology Thonburi in the first semester of the academic year 2019. They were chosen using purposive sampling method out of those who were willing to participate in interactive exhibition and fill out the questionnaire.

\subsection{Research Variables}

a. Independent variable was the development of electronic book with QR code technology and interactive exhibition entitled "Media Literacy" for undergraduate students.

b. Dependent variables were as follows:

- The needs regarding the development of the electronic book with QR code technology and interactive exhibition entitled "Media Literacy" for undergraduate students

- The quality of the contents and the media presentation of the electronic book with QR code technology and interactive exhibition entitled "Media Literacy" for undergraduate students

- The learning achievement of the sampling group after using the electronic book with QR code technology and interactive exhibition entitled "Media Literacy" for undergraduate students

- The satisfaction of the sampling group towards the electronic book with QR code technology and interactive exhibition entitled "Media Literacy" for undergraduate students

\section{Research Methodology}

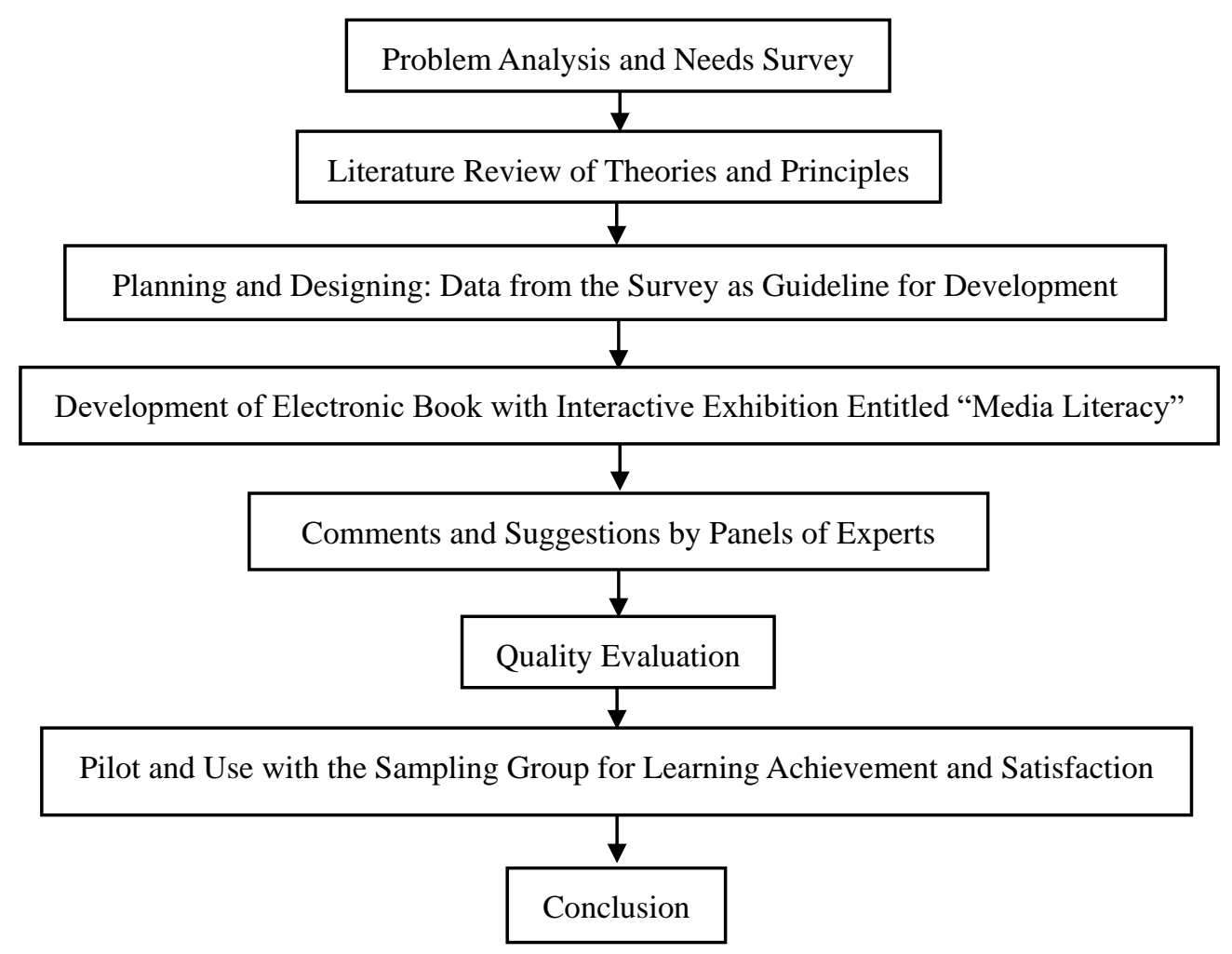




\section{Research Tools}

a. The needs survey form regarding the development of the electronic book with QR code technology and interactive exhibition entitled "Media Literacy" for undergraduate students

b. The electronic book with QR code technology and interactive exhibition entitled "Media Literacy" for undergraduate students

c. The quality evaluation forms for the development of the electronic book with QR code technology and interactive exhibition entitled "Media Literacy" for undergraduate students

d. The learning achievement test entitled "Media Literacy" for third-year undergraduate students from Department of Educational Communications and Technology, Faculty of Industrial Education and Technology, King Mongkut's University of Technology Thonburi

e. The satisfaction questionnaire for the sampling group towards the electronic book with QR code technology and interactive exhibition entitled "Media Literacy"

\section{Data Analysis}

The statistical methods for this study were percentage, mean score, standard deviation (S.D.), index of congruence (IOC) and the statistical method for learning achievement involved t-test dependent variables (Boontam Kitpreedaborisut, 2006).

\section{Research Findings}

Table 1. Shows the findings from the needs survey of the sampling group

\begin{tabular}{|l|c|c|c|}
\hline \multicolumn{1}{|c|}{ Item } & $\overline{\mathbf{x}}$ & S.D. & Level of needs \\
\hline 1. Use of electronic book & 4.70 & 0.46 & The highest \\
\hline 2. Needs for contents & 4.67 & 0.48 & The highest \\
\hline 3. Needs for design & 4.65 & 0.50 & The highest \\
\hline 4. Needs for QR code technology & 4.66 & 0.47 & The highest \\
\hline 5. Needs for interactive exhibition & 4.74 & 0.45 & The highest \\
\hline \multicolumn{1}{|c|}{ Average } & $\mathbf{4 . 6 8}$ & $\mathbf{0 . 4 7}$ & The highest \\
\hline
\end{tabular}

According to Table 1, the sampling group expressed the highest level of needs for the development of the electronic book with QR code technology and interactive exhibition entitled "Media Literacy" for undergraduate students $(\overline{\mathrm{x}}=4.68$, S.D.= 0.47). The findings confirmed one of the research hypotheses. Therefore, the researchers developed the electronic book as shown below.

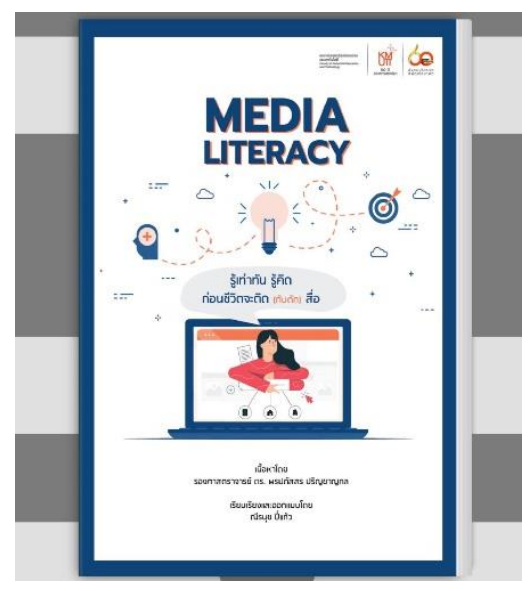



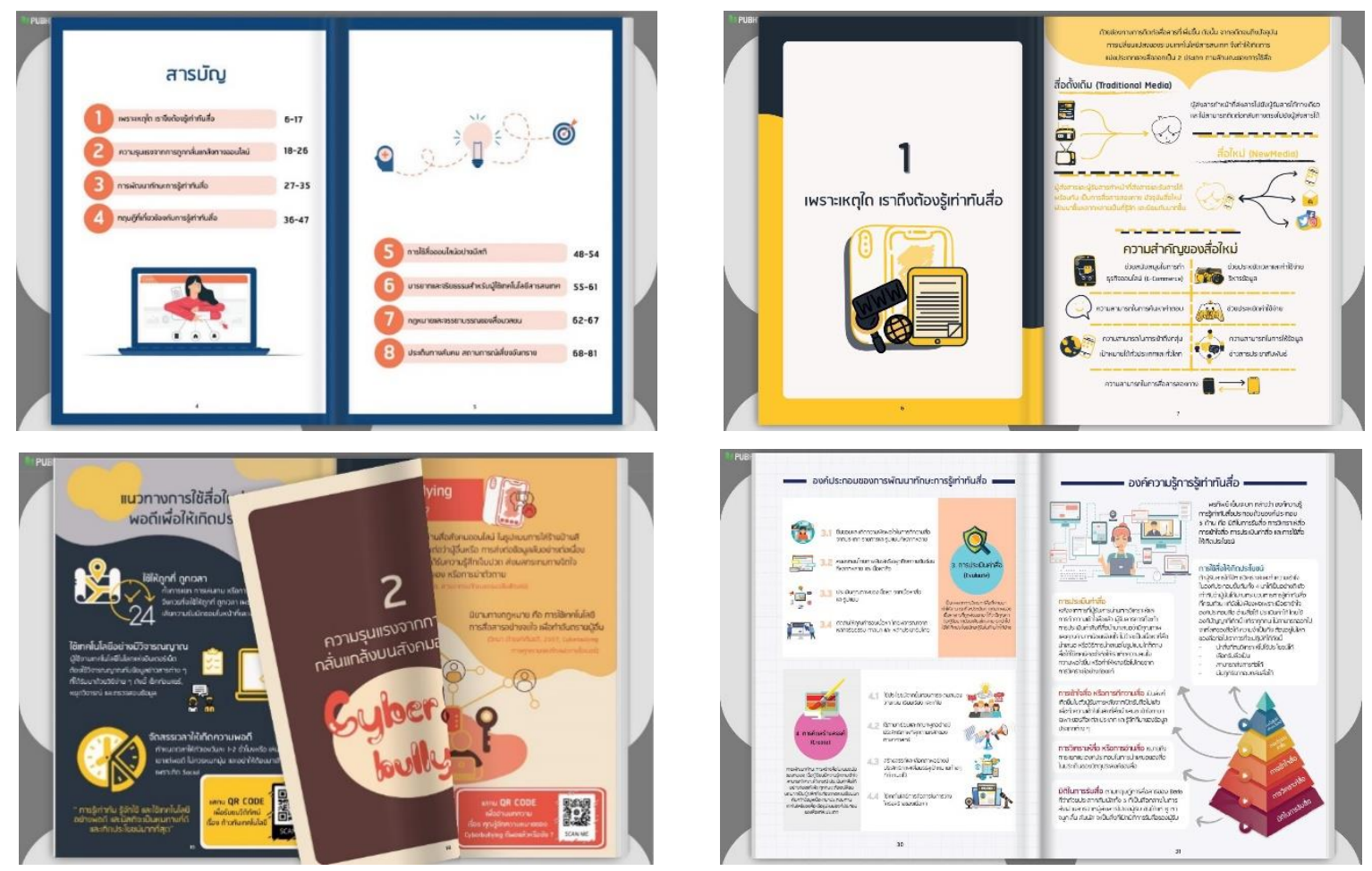

Figure 1. Shows the developed electronic book

The developed electronic book with QR code technology and interactive exhibition entitled "Media Literacy" for undergraduate students contained 8 units as follows: 1) Why do we need media literacy?; 2) Dangers of cyberbullying; 3) How to develop media literacy skills; 4) Theories related to media literacy; 5) How to use online media with awareness; 6) Netiquette and ethics of IT users; 7) Law and moral code of mass media; and 8) social issues and risky situations. The electronic book was designed to contain texts, graphic images, contents alongside video clips through the application of QR code technology.
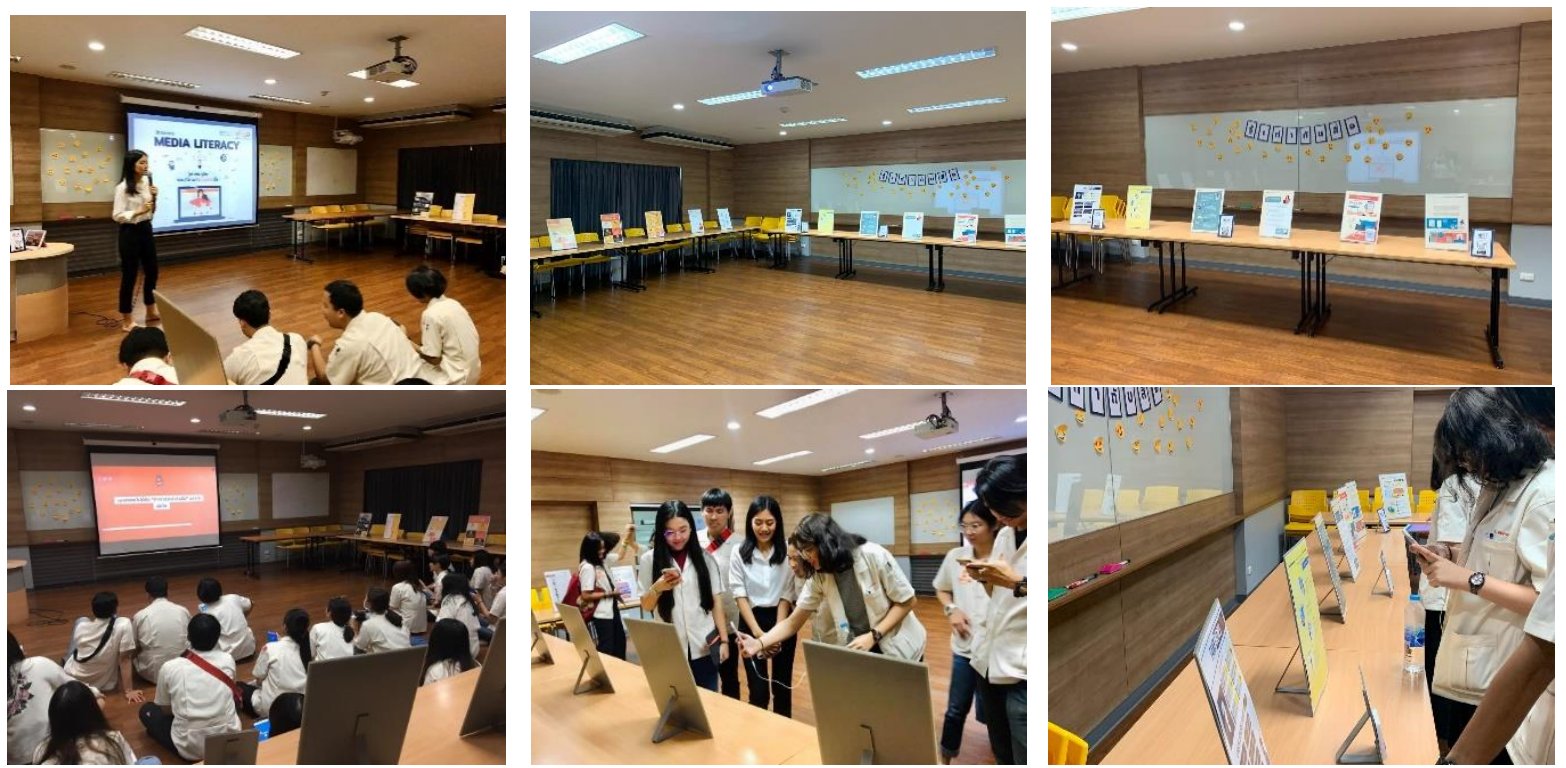

Figure 2. Shows the interactive exhibition

The interactive exhibition entitled "Media Literacy" contained the information from the electronic book and it was adapted to fit the exhibition theme, that is, "to be aware of the dangers before getting trapped". The information was distributed through infographic posters. During the exhibition, the researchers added activities to engage with the sampling group including how to scan QR code to view the electronic book, how to access supplementary video clips, and quiz show so that learners could participate in the activities to gain knowledge through the exhibition. 
Table 2. Shows the quality of the contents and the media presentation

\begin{tabular}{|l|c|c|c|}
\hline \multicolumn{1}{|c|}{ Item } & $\overline{\mathbf{x}}$ & S.D. & Quality level \\
\hline Contents & 4.73 & 0.42 & Very good \\
\hline Media presentation & 4.42 & 0.40 & Good \\
\hline
\end{tabular}

According to Table 2 , the quality of the contents as evaluated by the experts in contents was at a very good level $(\overline{\bar{x}}=4.73$, S.D. $=0.42)$ and the quality of the media presentation was at a good level $(\overline{\mathrm{x}}=4.42$, S.D. $=0.40)$. The findings confirmed one of the research hypotheses.

Table 3. Shows the learning achievement test results

\begin{tabular}{|c|c|c|c|c|c|c|}
\hline Test & $\mathbf{N}$ & $\overline{\mathbf{x}}$ & $\mathbf{S}$ & t & df & sig \\
\hline Pre-test & 40 & 10.60 & 24.25 & & & \\
\cline { 1 - 5 } Post-test & 40 & 17.20 & 4.27 & 7.23 & 39.00 & $0.00^{*}$ \\
\hline
\end{tabular}

* with statistical significance at the .05 level

According to Table 3, the learning achievement test results showed that their average post-test score of the undergraduate students who used the electronic book with QR code technology and interactive exhibition entitled "Media Literacy" was higher than their average pre-test score with statistical significance at the .05 level $(\mathrm{t}$-test $=7.23)$. The findings confirmed one of the research hypotheses.

Table 4. Shows the satisfaction of the sampling group

\begin{tabular}{|c|c|c|c|}
\hline Item & $\overline{\mathrm{x}}$ & S.D. & Satisfaction level \\
\hline 1. Contents & 4.71 & 0.46 & The highest \\
\hline 2. Fonts and texts & 4.68 & 0.49 & The highest \\
\hline 3. Design & 4.79 & 0.41 & The highest \\
\hline 4. Usage & 4.63 & 0.51 & The highest \\
\hline 5. QR code technology & 4.63 & 0.50 & The highest \\
\hline 6. Exhibition & 4.63 & 0.56 & The highest \\
\hline Average & 4.68 & 0.49 & The highest \\
\hline
\end{tabular}

According to Table 4, the sampling group expressed the highest level of satisfaction towards the electronic book with QR code technology and interactive exhibition entitled "Media Literacy" for undergraduate students $(\overline{\mathrm{x}}=4.68$, S.D. $=0.49)$. The findings confirmed one of the research hypotheses.

\section{Research Discussion}

According the needs survey, the sampling group expressed the highest level of needs regarding the development of the electronic book with QR code technology and interactive exhibition entitled "Media Literacy" for undergraduate students $(\overline{\mathrm{x}}=4.68$, S.D.= 0.47). One of the ideas was from the research study by Kanitha Sangkajang et al. (2014) who used hypermedia in the development of electronic book to increase skills among students so that students could think in different skills better. Regarding the survey on the needs for QR code technology, the researchers followed the research study by Kwanjutha Kambanlue, Wiwat Meesuwan and Pichayapha Yuangsoi (2017) who applied QR code technology to promote learning activities at Her Royal Highness Princess Maha Chakri Sirondhorn Collection of Banana Species Center in Kamphaengphet in order to make it more convenient for people to access the information regarding banana species. Regarding the interactive exhibition, the researchers followed the research study by Sumetwit Chaolumbua and Wiwat Meesuwan (2015) who used learning exhibition in common with the QR code technology on the topic of ASEAN for Mathayom Suksa 4 students of Thapsalaprachasan School, Nakhon Sawan Province because the students participated in the exhibition and learned by themselves through different kinds of media. In other words, exhibition could gain attention from learners and learners could understand abstract contents better.

During the development of the electronic book, the researchers used the principles of ADDIE Model (Abhicha Anukulwech, 2019) to design the media. The quality of the contents was at a very good level ( $\overline{\mathrm{x}}=4.73$, S.D. $=0.42$ ) and this was similar to the research by Kawissara Thongdee (2014) who developed the level of media literacy by using training package of augmented reality on "Media Literacy for Children and Youth" in that the use of new media and technology helped learners to learn by themselves and to engage in collaboration. Another similar research by Sujitra Sara-in (2015) who developed digital network training procedure enhancing critical thinking on media literacy for leading students who attended ICT media literacy project showed that by studying related theories, the researchers could develop the foundation for learning and media literacy, resulting in better measurement in media literacy. Students could gain media literacy when the training package was carefully designed for effective learning. 
The quality evaluation showed that the quality of the media presentation was at a good level $(\overline{\mathbf{x}}=4.42$, S.D. $=0.40)$. This is similar to the study by Peera Wongtee (2015) who developed digital contents on portable computers as media entitled "Advanced Graphics and Animation for Communication" because the developed media must be easy to understand with clear fonts in order to help learners read the media easily.

The learning achievement test results showed that their average post-test score was higher than their average pre-test score with statistical significance at the .05 level. The average post-test score was 17.20 with standard deviation of 4.27 $(\overline{\mathrm{x}}=17.20$, S.D. $=4.27)$. This was similar to research by Sujitra Sara-in $(2015)$ who developed digital network training procedure enhancing critical thinking on media literacy for leading students who attended ICT media literacy project in that media literacy could be integrated in other courses because learners could study the contents on their own anytime anywhere if they have internet connection. Students can practice until they fully understand the contents; hence, their understanding of the current situation.

The sampling group expressed the highest level of satisfaction towards the media $(\overline{\mathrm{x}}=4.68$, S.D. $=0.49)$. This is similar to the theories and principles of factors which contribute to satisfaction. To measure the satisfaction, Likert's scale was used (Chawalit Chukampang, 2018) in order to measure the level of satisfaction. This research was similar to the research by Worada Narkkasem (2012) who developed interactive electronic book on premedia process in that electronic books are interesting and they can be used effectively in classroom and for learning. It is also similar to the research study by Weerawit Jirojrat (2017) who developed printed matter for publicity through QR code technology entitled "Agricultural Tourism in Bang Mod Area" in that the printed matter for publicity through QR code technology was of very good quality and that it could really be used for publicity for the Bang Mod area.

\section{Conclusion}

According to the findings from this research into the development of the electronic book with QR code technology and interactive exhibition entitled "Media Literacy" for undergraduate students, the sampling group expressed the highest level of needs regarding the development of electronic book. The quality evaluation showed that the quality of the contents as evaluated by the experts in contents was at a very good level. The quality of the media presentation as evaluated by the experts in media presentation was at a good level. The learning achievement test results showed that the average post-test score was higher than the average pre-test score with statistical significance at the .05 level. The sampling group expressed the highest level of satisfaction towards the developed media. It can be concluded that the developed media could be distributed for further use.

\section{Research Suggestions}

\subsection{Suggestions From Research Findings}

a. The developed electronic book with QR code technology and interactive exhibition entitled "Media Literacy" for undergraduate students could really be used in any courses related to media literacy.

b. The developed electronic book with QR code technology and interactive exhibition entitled "Media Literacy" for undergraduate students could be used as additional activity outside the classroom to promote students to be aware of media literacy which is an important skill in the $21^{\text {st }}$ century as part of augmented reality (AR) and virtual reality (VR).

c. The developed electronic book with QR code technology and interactive exhibition entitled "Media Literacy" for undergraduate students could be used as a case study to develop electronic book in other topics regarding the $21^{\text {st }}$ century learning skills such as how to be well aware of information technology and how to communicate better.

\subsection{Suggestions for Further Research}

a. There should be a research study into the behaviors and attitudes regarding media literacy among students in similar courses in order to gain more coverage and to be used as guideline to increase the effectiveness of instruction and learning.

b. There should be a study into the development of electronic book with other technologies to improve the learning achievement of children and youth and those who are interested.

c. The findings and experience from the development of the electronic book with QR code technology and interactive exhibition entitled "Media Literacy" for undergraduate students could be used as guideline to develop contents in other courses. 


\section{References}

Anukulwech, A. (2014). Principles of ADDIE MODEL. Retrieved September 18, 2017, from http://lms.thaicyberu.go.th/

Bonrojwong, N., \& Praporntrakarn, K. (2017). A Variety of QR Code. Journal of the Association of Private Higher Education Institutions of Thailand under the Patronage of Her Royal Highness Princess Maha Chakri Sirindhorn, $6(1), 117$.

Chaolumbua, S., \& Meesuwan, W. (2015). The application of quick response code technology for encourage to promote learning activities at her royal highness princess maha chakri sirindhorn collection of banana species in kamphaengphet. Journal of Social Communication Innovation, 3(2), 49-50.

Chatmueangpok, N. (2009). Exhibition. Retrieved December 10, 2018, from http://kroobannok.com/blog/6709

Chukampang, C. (2018). The Development of Cognitive Domains through Likert's Scale. Retrieved September 18, 2018, from http://www.elearning.msu.ac.th/opencourse/0506704/page06_03_02.html

Jirojrat, W. (2017). The Development of Printed Matter for Publicity through QR Code Technology Entitled “Agricultural Tourism in Bang Mod Area". Master's dissertation in Industrial Education (Learning Technology and Mass Communication). King Mongkut's University of Technology Thonburi, Faculty of Industrial Education and Technology, p. B.

Kambanlue, K., Meesuwan, W., \& Yuangsoi, P. (2017). The Application of Quick Response Code Technology to Promote Learning Activities at Her Royal Highness Princess Maha Chakri Sirondhorn Collection of Banana Species Center in Kamphaengphet. Journal of Education Naresuan University, 19(1), 184.

Kitpreedaborisut, B. (2006). Technique in Creating Research Tools for Data Collection. Bangkok: Chamchuri Product, P45-46.

Ministry of Education. (2013). Information Technology and Communication for Education for 2014-2016. Bangkok: Ministry of Education, p. 26.

Narkkasem, W. (2012). The Development of Interactive Electronic Book on Premedia Process. The 50th Kasetsart University Academic Conference in Education, Economics and Business Administration, Humanities and Social Sciences (p. 105). Bangkok: Kasetsart University.

Pan-in, P. (2014). Research and Development on Learning Process for Promoting the Media Literacy for Thai Youth Based on Contemplative Education. Journal of Education Studies, 42(2), 32-44.

Registrar's Office, KMUTT. (2019). Schedule and Timetables (for Each Department) in the First Semester of the Academic Year 2019 for Undergraduate Students. Retrieved July 28, 2019, from http://regis.kmutt.ac.th/ service/schedule_tb/table162/all/ETM-2.pdf

Sangkajang, K. et al. (2014). The Development of Electronic Book for Learning Science in Local Communities through Tablets. Journal of Rajabhat Research, 3(2), 229.

Sara-in, S. (2015). A Development of Digital Network Training Procedure Enhancing Critical Thinking on Media Literacy for Leading Students Who Attended ICT Media Literacy Project. Master's dissertation in Industrial Education (Learning Technology and Mass Communication). King Mongkut's University of Technology Thonburi, Faculty of Industrial Education and Technology, p. B.

Siricharoen, N. (2015). Communication model for media literacy and information from the media, Internet Thailand Youth. Sripatum Review Humanities and Social Sciences, 15(1), 45-55.

Soonghanghwa, S. (2009). The Development of Electronic Book through Branch Storytelling for Grade 5 Students at Anuban Ponthong School. Journal of Roi-Et Teachers Zone 3, 3(1), 35-40.

Sopontammark, A. (2017). Media Literacy for Information Technology and Digital Age.

Tongdee, K. (2014). The Development of Media Literacy Levels by Using Training Package of Augmented Reality on "Media Literacy for Children and Youth". Master's dissertation in Industrial Education (Learning Technology and Mass Communication). King Mongkut's University of Technology Thonburi, Faculty of Industrial Education and Technology, p. B.

Wiwatpanit, N. (2015). The Development of Media Literacy for Online Communities. Journal of Graduate Studies Valaya Alongkorn Rajabhat University, 9(3), 210-219.

Wongtee, P. (2015). The Development of Digital Contents on Portable Computers as Media Entitled "Advanced Graphics and Animation for Communication". Proceedings of National and International Conference and Research Presentation in the Education Field (p. 25-26). Bangkok: Suan Sunandha Rajabhat University. 
Yimpraset, U. (2014). Media Literacy. Bangkok: Office of the National Broadcasting and Telecommunications Commission, p. 1.

\section{Copyrights}

Copyright for this article is retained by the author(s), with first publication rights granted to the journal.

This is an open-access article distributed under the terms and conditions of the Creative Commons Attribution license (http://creativecommons.org/licenses/by/4.0/). 